N8 179

EXCESS VOLATILITY OF STOCK PRICES AND KNIGHTIAN UNCERTAINTY

JAMES DOW E

SERGIO RIBEIRO DA COSTA WERLANG

1991 


\title{
Excess Volatility of Stock Prices and Knightian Lncertainty
}

\author{
by \\ James DOW \\ London Business School
}

Sussex Place, Regent's Park. London NW1 ASA. LK

and

Sérgio Ribeiro da Costa WERLANG

EPGE-Fundaçāo Getúlio Vargas

10-Andar, Praia de Botafogo 190. Botafogo CEP 22250

Rio de Janeiro-RJ, Brazil

European Economic Association

Cambridge

Annual Congress 1991 


\section{Introduction}

This paper has two themes, both of which have preoccupied economists for many years. The first is the volatility of stock prices. It has long then suggested that the erratic movements of stock prices are incompatible with rational investor behaviour. More recently, formal empirical tests have been devised which suggest that stock prices are excessively volatile. These tests show apparenty systematic violations of a variance bounds inequality.

The second theme is the question of how a rational person should hehave under uncertainty. particularly when he or she has little information about the form of the uncertainty. Knight (1921) was a notable proponent of the view that this type of uncertainty is qualitatively different from risky situations where the parameters of the risk are well-knoun to the decision maker. However, the currently standard model in economics, due to Savage (1954), predicts that agents should have subjective probability distributions which do not make this distinction.

In this paper, we show that models which formalize krightian uncertainty can he used to explain high stock price volatility. We provide an example in which the variance bound is viclated. Since the future profitability of companies depends heavily on many long-term factors. including political fastors, which are extremely difficult to predict. it is natural to think that the stock market is characterized by a high degree of Knightian uncertainty. Therefore, we suggest this type of behaviour under uncertainty as a possible explanation of the high volatility of stock market prices.

\section{Excess Volatility}

The variance hounds restrictions were developed by LeRoy and Porter (1981) and Shiller (1981). Here we give only the briefest outine of the resurictions and the evijence: the reader is referred to LeRoy : (1989) survey and Shiller's (1989) book for further details and references. The starting puint is the principle that if agents are risk-neutral an asset's price should egual the expectation of the discounted value of the future dividends. Here we will assume for simplicity a sinzaron where the asset pays a single liquicating dividend with present value $V$ and the eurent price i. P. P depends an the agen: v informajon set. 1. The aralysis applies to the general stse with man! dividend rayments if $V$ iv interpreted to the the present value of the iscure divid:nis. Thus 
$P=E(V ! I)$

The variance tounds inequality is derived from the condition

$\operatorname{Var}(V)=\operatorname{Var}\left[E\left(V_{i} I\right)\right]+E_{1}\left[\operatorname{Var}\left(V_{i} I\right)\right]$

which is in turn an immediate consequence of the relation $E(V)=E[E(V \mid I)]$. Since variances are nonnegative and the price equals the expected value.

$\operatorname{Var}(V) \geq \operatorname{Var}(P)$.

To test this requires some statistical assumptions. For example. if we had a large number of such assets whose liquidation values were iid, we could simply compare the sample variance of the set of prices and the set of realized values. The empirical studies (LeRoy and Porter (1981), Shiller (1981)) used time series data on stock prices and dividend realizations, assuming a stationary dividend process (later studies, eg Campbell and Shiller (1988), made weaker assumptions on the dividend process).

How do the variance bounds apply to a situation of Knightian uncertainty? Then the agent does not know the actual probability distribution of the value. A risk neutral agent who satisties the Savage axioms has a subjective probability distribution. This subjective distribution uill in general differ from the actual distribution, and so the variance hound can he violated in a probabilistic sense (hecause the expectation, under the actual distribution. of the conditional expectation under the suhjective distribution, will in general differ from the a:tual unconditional expectation). However. it seems implausible to explain the large amount of evidence that has been collected by saying that agents systematically have subjective distributions with higher variance than actual distributions (although logically, this argument is juhious because it implies that the agent effectively knous the true probability distribution of the states hut with a less presise information setl. We therefore rurn in another explanation: that the agents decisions, in siruavons of Krightian unertainty. are nut represented by subjective protability distrinutions.

\section{lincertaint! Aversion}

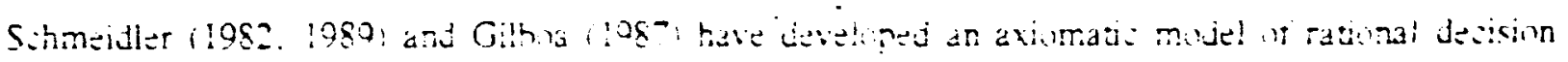

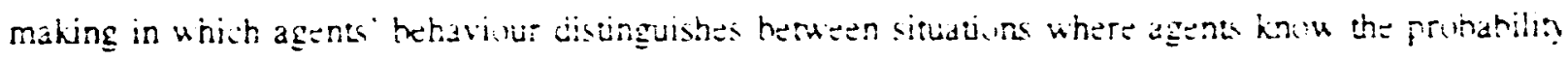

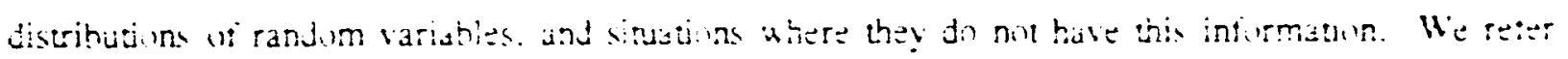


to the former as risk and the latter as uncernainfy, or Knightian uncertainty. Synonyms that are used in the literature include roulette lottery, for risk, and horse lottery and ambiguity, for uncertainty. We now give a very brief exposition of the main aspects of the model. The reader is referred to the papers by Schmeidler and Gilhoa cited above for.a complete description and for the underlying axioms, and to Dow and Werlang (1991) which contains an example and an application to porttolio choice. Simonsen and Werlang (1991) also describe the implications for porttolio choice. Bewley (1986) presents a similar model which is also designed to capture Knightian uncertainty. His model predicts that uncertainty leads to inertia, a tendency to favour the starus quo. while in Schmeidler-Gilbra there is a tendency to choose acts where the agent does not end up hearing uncertainty.

The Schmeidler-Gilboa model predicts that agents' hehavior will he represented by a utility function and a (subjective) non-additive prohability distribution. A non-additive probability p reflecting aversion to uncertainty satisfies the condition

$p(A)+p(B) \leq p(A \cup B)+p(A \cap B)$.

rather than the stronger condition satisfied by (additive) probabilities:

$p(A)+p(B)=p(A \cup B)+p(A \cap B)$.

In particular. $p(A)-p\left(A^{c}\right)$ may be less than 1: the difference can the thought of as a measure of the uncertainty attached by the agent to the event A.

The agent maximizes expected utility under a non-additive distribution, where the expectation of a non-negative random variable $\mathrm{X}$ is defined as:

$E(X)=\int_{\overline{\mathbf{R}}}-p(x \geq x) d x$.

Associated with a non-additive prohability $\mathrm{p}$ is a sei $د$ of additive protiabilities called the core of $\mathrm{p}$. which is defined (analogousiy w the core in exprerative game theory) as the set ot additive probahiling measures $x$ suich that $\pi(A) \geq P(A)$ for all events $A$. If the non-addicive probabiitit satisties inequation (2) (retlecting aversion to uniertainty) the sore is non-empty. (A closely related model of tehavior under uniercingry is for the agent to aci to maximize the minimum value. wer the elements of the core.

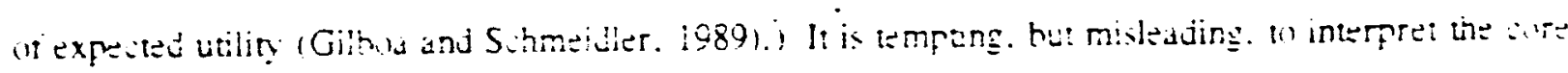

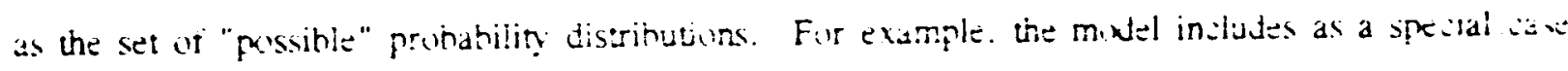

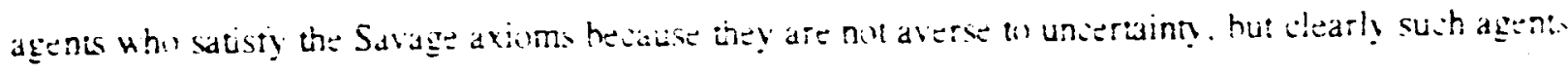


do nut necessarily know the true probability distribution. However, for the analysis helow we will need some relationship hetween the subjective non-additive distributions which represent agents' hehaviour. and the frequencies observed by the econometrician. We will therefore assume that the econometrician observes realizations drawn from one elemient of the core.

When agents' preferences satisfy Savage's axioms, it is natural to assume that they update according to Bayes' rule. Although this is not a consequence of Savage's model, many consideratons point to Bayes' rule (the standard argument is given in Kreps (1988): Broun (1976) goes further. showing that it is optimal for agents to use Bayes' rule). With non-additive probabilities, the situation is not so clear but the Dempster-Shafer rule is the natural generalization of Bayes Rule iDempster. 1968 and Shafer, 1976). Dow, Madrigal and Werlang (1989) use the Dempster-Shafer rule. Schmeidler and Gilboa (1991) provide an axiomatic foundation for the Dempster-Shafer rule. The updating rule is:

$p\left(A_{i}^{\prime} B\right)=\left[p\left(A \cup B^{c}\right)-p^{\left(B^{i}\right)}\right] /\left[1-p\left(B^{i}\right)\right]$.

We now apply this model to an example of equilibrium in a stock market with Krightian uncertainty.

\section{An Example}

There are three periods $t=0.1 .2$. There is one risky asset in positive net supply ("the asset") and a safe asset (cash). The riskless rate of return is zero or, equivalenty. all values may he interpreted as present values discounted at the sate interest rate.

The asset will pay a liquidating dividend $V$ at time $t=2$. There are three states 'i nature $i$.

2 and 3. The value of $V$ is different in each state and is, respectively. $\quad$. . : or 0 .

Agents are all identical. and are risk neutral. In period $t=1$. agents :ezeive (puhlic)

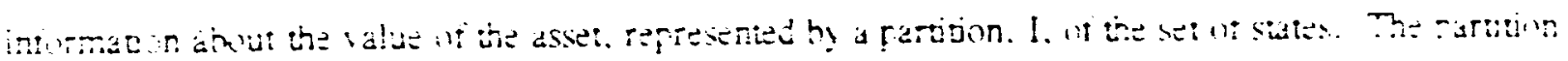

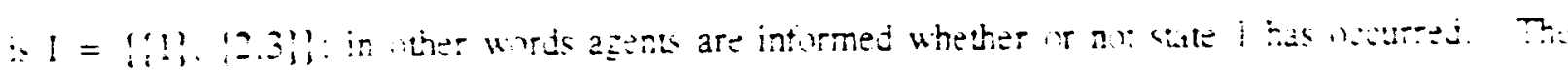

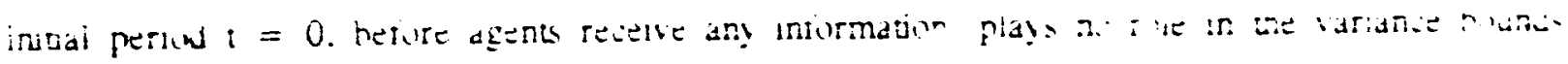

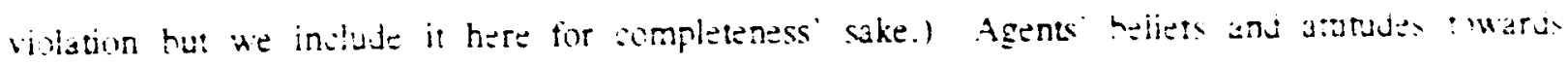
uncertaing are represented by the folluking nun-addivive probability messurs: 
$p_{1}=p_{2}=p_{3}=1 / 4$

$\Gamma_{1:}=\Gamma_{21}=p_{12}=1 / 2$

Here $p_{1}$ is the (non-ddditive) prohability of state $i$ or $j$ : hecause equaton 13 ) does nol hold it 1 necessary to specify these in addition to the (non-additive) prohahility of each state. The core. $د$. if this measure is the convex hull of the following three (additive) prohahiiin measures:

$\pi_{1}=1 / 2, \pi_{2}=1 / 4, \pi_{3}=1 / 4$

$\pi_{1}=1 / 4, \pi_{2}=1 / 2, \pi_{3}=1 / 4$

$\pi:=1 / 4, \pi_{2}=1 / 4, \pi_{3}=1 \%$

Let $P$ : denote the price at time $t$. Then since the asset is in nositive net suppiy. it follows IDius and Werlang. 1991) that $P_{n}=E(V), P_{:}=E\left(V^{\prime} I\right)$, and naturaily $P_{z}=i$. Thus in the initial periou. $\left.P_{1}=E(V)=0-(1:-0) P:=-11-: \because\right) P_{:}=\$ 8$

If the agents receive gork news state $i$ i then $P:=1$. li is straigntioruard in snou that this

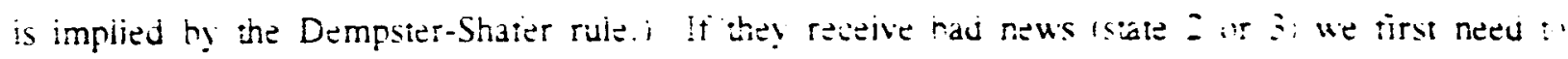
:alculate the conditional prohability of state 2. By the Dempster-Shater rule requation (4)) this is given ?

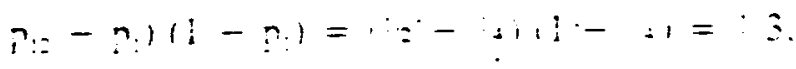

W the price is $P_{:}=16$.

To summarize:

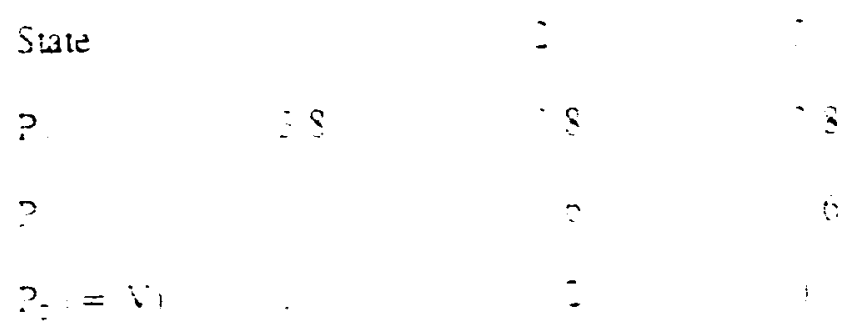

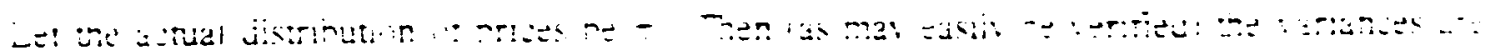

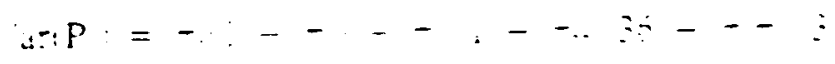

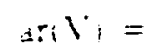

atis 
clear what relationship $\pi$ should hear to the subjective non-additive distribution $\mathrm{p}$. For example, if the agent were not uncertainty averse $p$ would he an adjitive distrihution. hut since this is consistent with the agent not knowing the distrihution. it would he quite natural to have $p \neq \pi$. Vevertheless. for the reasons outlined above. we will assume that $\pi \in د$, where $\perp$ is the core of $p$.

For $x \in \Delta$, the variance of $P_{1}$ ranges over the interval $[25 / 192 . i 00.576 \mid=[0.1302 .0 .1736 \mid$. while the variance of $V$ ranges over the interval $18 / 64,11 / 641=10.1250,0.17191$. Soltice that hoth endpoints of the interval of possible variances are larger for the price than for the value. This is a stronger property than having an element of $I$ for which the value has lower varlance than the price.

For the three prohahility distributions listed anove. se nave:

In the case of $(7) . \pi_{1}=1, \pi_{z}=i_{i}, \pi_{i}=i$.

$\operatorname{Var}\left(P_{1}\right)=0.1736 . \operatorname{Var}(V)=0.1719$. violating the variance nound.

In the case of $(8), \bar{\pi}=i, \bar{i}=: \bar{i}:=i$.

$\operatorname{Var}\left(P_{:}\right)=0.1302 . V$ arr $(1)=0.1250$. viaung the :ariance round.

In the case of $(9), \pi:=i_{4}, \pi_{z}=i_{4}, \pi=1 \%$.

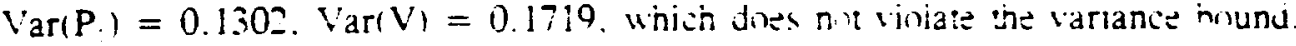

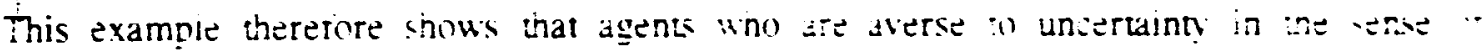
Schmeiuler and Gilboa may violate une variance mund inecuaity.

\section{Absence of Arbitrage Opportunity}

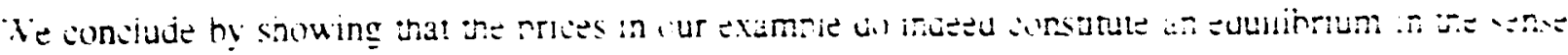

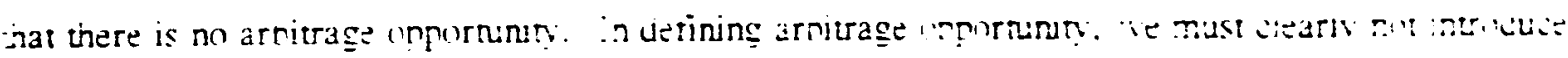

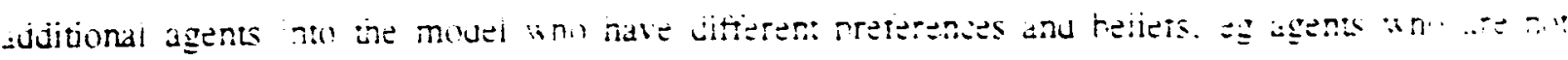

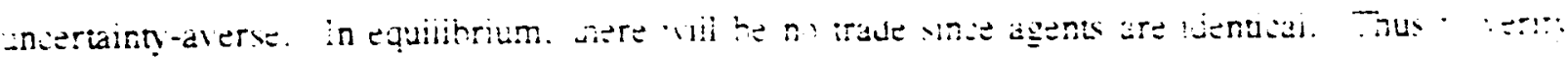

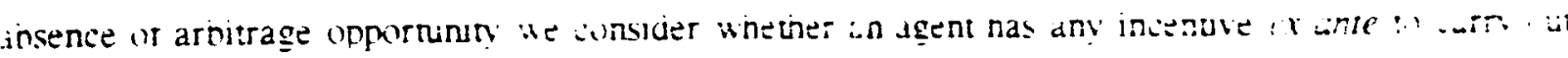

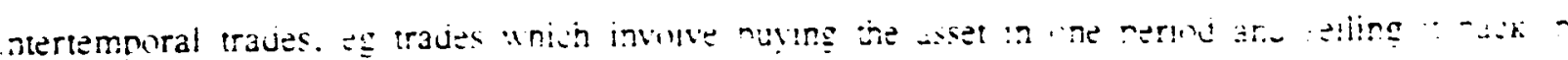
anther nersous.

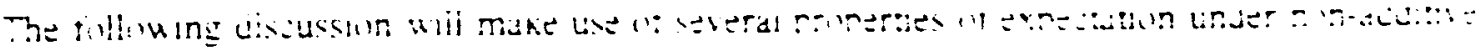

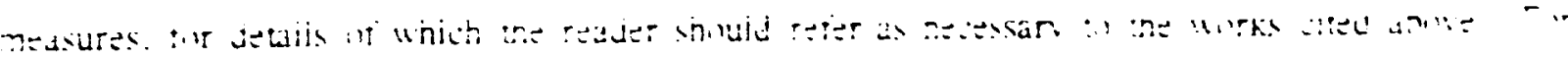


example. $E(\lambda X)=\lambda E(X)$ for $\lambda \geq 0$ while $-E(-X) \geq E(X)$, also $E(X+Y) \geq E(X)+E(Y)$ hut with equality in case $X$ and $Y$ sausty a condition called comonotonicity.

An example of an arbitrage strategy is tor an agent to buy an extra unst in perion 0 and sell it again in period 1 . Assuming without loss of generality that the initial holding is une unit. the expected utility from this strategy is $E\left[V(s)-P_{n}-P_{(s)}(s)\right.$ and from continuing wo hold the asset is is E|V(s)|. Here random variables have theen explicitly expressed as functions of the state of nature, s. for clarity. We therefore require

$E\left[V(s)-P_{n}-P_{i}(s)\right] \leq E[V(s)]$.

ur. by comonotunicity of $V(s)$ and $P_{:}(s)$.

$E[V(s)]-P_{0}-E\left[P_{1}(s)\right] \leq E[V(s)]$

is $P_{n} \geq E\left[P_{i}(s)\right]$. In the example, we have

$E[P(s)]=1.6-(1-1: 6 \times 14)=3.8=P$

$=0$ ine arbiurage is not protitabie.

Equally, the agent must not have an ineentive to sell the asset and huy it hack one neriod later: $E[(i s)-P-?(S)] \leq E_{i}[(s)]$.

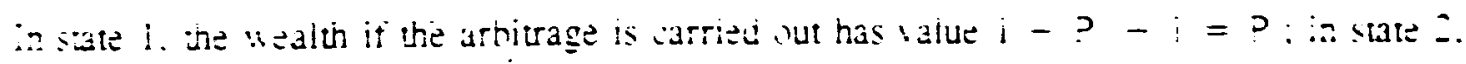

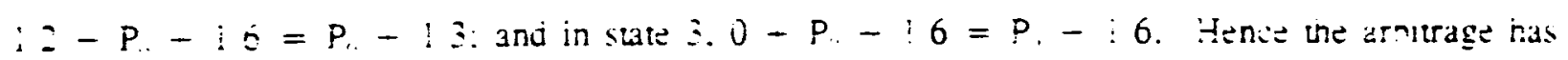
expected value

$$
P .-161-1(6.121-113.141=P=E[(i s) \mid .
$$

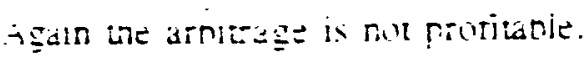

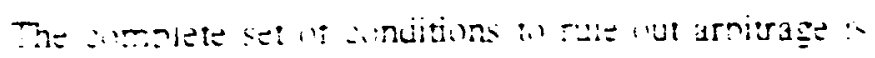

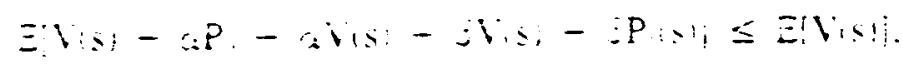

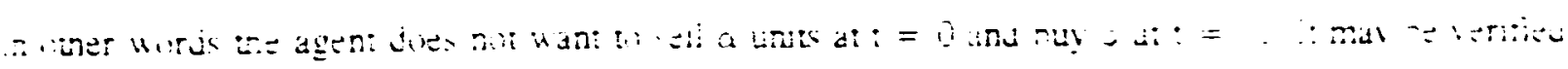

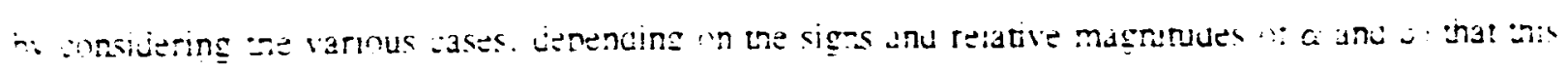

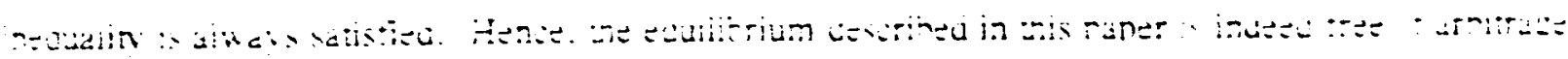
nent: ans 
Acknowledgements: This research was done while Dow was visiting EPGE-Fundação Getrülio Vargas under a grant trım C.NPq. We thank Ailsa Riell and participants at the EEA Cong̨ress tur cumments.

\section{References}

Bewley, Truman. 1986. Knightian decision theory, part 1, working paper. Ciuvies Finundatun. Yale University.

Brown. Peter 11. 1976. Conditionalization and expected utility, Philosopiny of Science $+3 .+15-419$.

Camphell. John $Y$ and Rohert J Shiller. 1988. The dividend-price ratio and expectations if turture dividends and discount factors. Review of Financial Studies 1. 195-228.

Dempster. Arthur P. 1968. A generalization of Bayesian inference. Journal of the Royci Statisticai Socien (series B) $30.205-247$.

Dow. James anj Sergiv R Werlang. 1991. Risk aversion. unertainty atersun and the untmal inove of purtrilio. Econometrica, torthioming.

Dow. James. Vivente Madrigal and Sergio R Werlang. 1989. Common knowlejge. preterences and speculacve trade. Working faper. Lonjon Business S.hool and Fundacãn Gerilio Vargas.

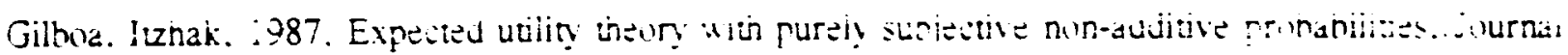
of Mathematical Economies 16. 6́5-88.

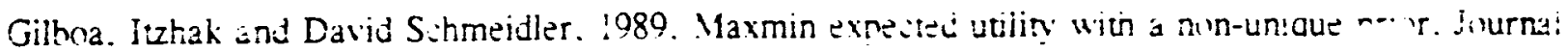
of Matizmatical Exonomics is. 1+1-1:3.

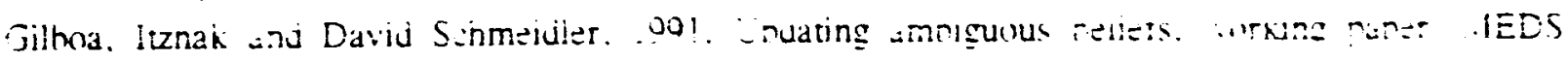
Virthuestern Conversity.

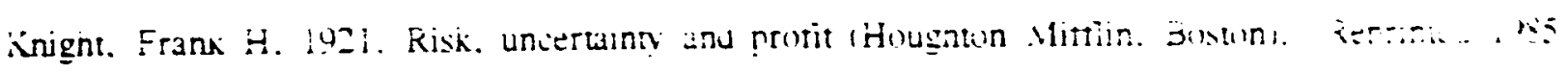
Liviversity of Chicago Press. Ciniagon.

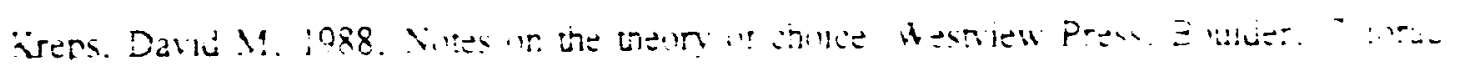

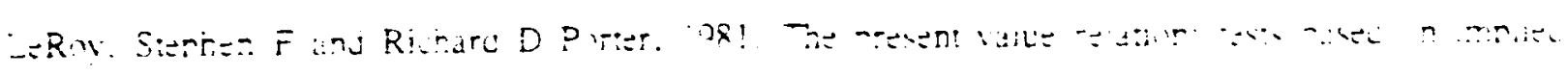

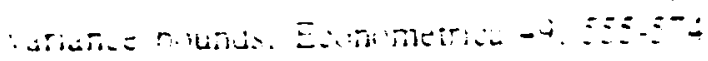

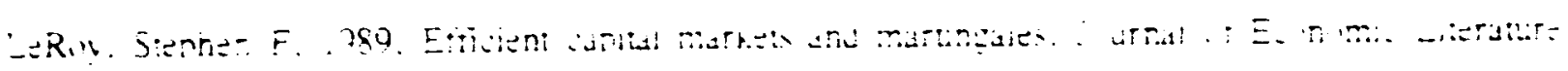

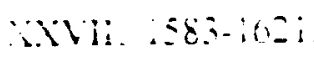


Savage, Leonard J, 1954. The foundations of statistics (Wiley. New York). Second edition 1972 (Dover, New York).

Sihmeidler. David. 1982, Suhjective prohahility withuut additivity ttempurary mel, working paper. Foerder Institute for Economic Research. Tel Aviv Lniversiry.

Schmeidler. David. 1989. Subjective prohability and expected utility without additiving. Esonometrica $57.571-587$.

Shafer, Glenn. 1976. A mathematical theory of evidence (Princetun Lniversity Press. Princelun. Vew Jerseyl.

Shiller, Robert J. 1981. Do sock prices move tow much to ne iustufied hy unseduent shanges a dividends?. American Ezonomic Reviek 71 , $+21-4: 36$.

Shiller. Rotert J. 1989. Market volatility (111T Press. Camoridge. Massactnuserksı.

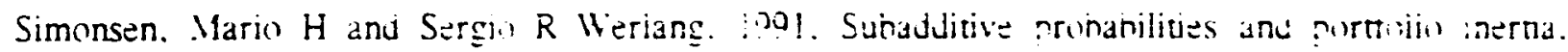
Revisia de Einumetria ierthooning. 
100. JUROS, PREÇOS E DIUIDA PÚBLICA VOLUME I: ASPECTOS TÉRICOS - Marco Antonio C. Miertins e Clovis de Faro - 1537 (esgotaco)

101. JUROS, PREÇCS E DIUIDA PÚGLICA VOLURE II: A ECONOHIA GRASILEIRA - IOTLGS - Antonic Salazar P. Erandão, Clóvis de "aro e Maroo A. C. Hartins - 1507 iescotado)

102. MACROECONOMIÁ KALECKIfiva - Fubens Fanha Cysne - 198 ?

103. O PREMID DO DÓLGR NO MERCADO PARALELO, O SUBFATURR.MENTO DE

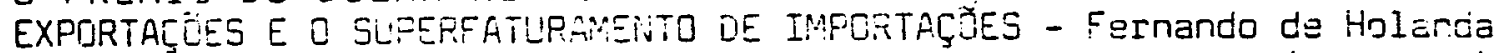
Bartosa - Rucens Fenha Eysre e Marcos Costa Holanda - 1987 (esgotado)

104. BRAZILIAN EXPERIENCE UITH EXTERNAL DEBT AND PROEPECTS FOR GRCLTHFernarido da hoianda Barbosa and Mantel Sancinez de. La Cal - 1937 (esgrtida)

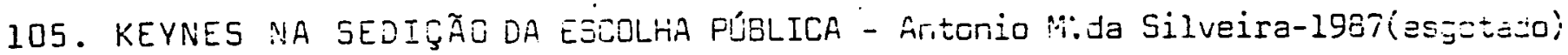

106. O TEOREMA DE FRUBENIUS-PERRON - Carlos Ivan Simansen Leal - 1987

1ú7. POPULAÇÃO BRAsileira - Jessé Monteilo-1937 (esgotado)

2C8. MACROECQNOMIA - CAPITLLO VI: "DEMANDA DOR MOEDA - Mario Henirique Simonsen e fubens Penina Eysne-1987 (esgotsjo)

109. MACROECONOMIA - CAFITULO VII: "DEMANDA AIREgADA E A CURVA is": - Mario Henrique Simonsen e Rubens Fenha Cysne - 1987 - (esgotaco)

110. MACROECONOMIA - MODELOS DE EQUILIBRIO GGREGATIVO A CURTO FRAZJ - Mario Henrique Simonsen e Pubens Penha Cysne-1987 (esgotado)

111. THE BAYESIAN FOUNDATIONS OF SDLUTION CONCEPTS OF GAMES - Sérgio Ribeiro da Costa Wariang a Tommy Chin-Chiu Tan - 1987 (esgotacio)

112. PREÇOS LIQUIDOS (PREÇCS DE VALOR ADICIDNADO) E SEUS DETERMINANTES; DE FRODUTCS SELECIONADOS, ND PERIODO 1980/10 Semestre/1906 - Reul Ekerman - 1987

113. EMPRÉSTIMOS BANCARIOS E SALDO-MÉdIO: O CASO DE PRESTAÇD̃E - Clovis de Faro - 1988 (esgotara)

114. A DINÂMICA DA INFLAÇÃo - Mario Henrique Simonsen - 198B (esgctado)

115. UNEERTAINTY AVERSION AND THE DPTIMAL CHOISE OF PORTFOLIO James - Dow e Sérgio Ribeiro da Costa Uerlang-1988. (esgotano)

116. O CIClo eCONômico - Mario Henrique Simonsen - 198g (esgctado)

117. FOREIGN CAPITAL AND ECGNUMIC GROUTH - THE BRAZILIFiN CASE STLOYMario tienrique simonsen - 1988

118. COMMON KNOWLEDEE - Sérgio Ribeiro da Costa berlang - 19as(esontato)

119. OS FUINDAMENTES OA A::ALISE MACROECONCMICA-Prof.Mario Henricie Simonsen e Prof. Rubens fentia fysne - 1998 (esgotada)

120. CAPITULO XII - EXPECTATIVASS RACIONAIS - Maric Henrique Simonsen - 1938 (esgotado)

121. A dferta agregada e mepigado ge trabalho - Prof. Mario Henriquia Simonsen e Prof. Rubens Periha Cysre - 198 b (esgotado)

122. INEREIA INFLACIONAAI E INFLAÇÃO INERCIAL. - Prof. Mario Hen: : :4? Simonen - 1998 (esgatado)

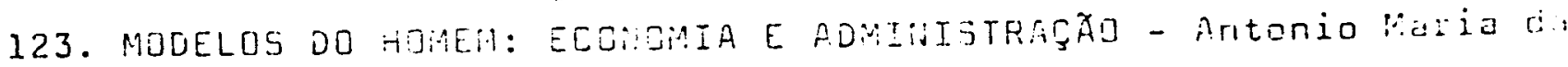
Silveiza - 1960

124. WMOERINURICIAC OF EXPJRTS, DUERINUOILING OF IMPORTS, AND THF

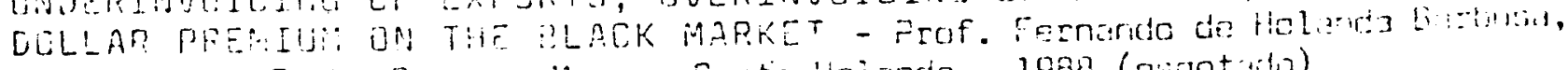

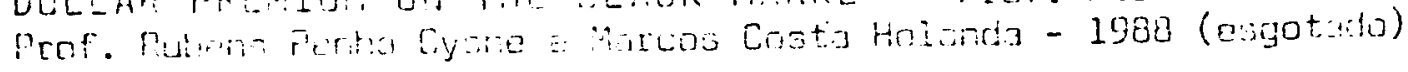




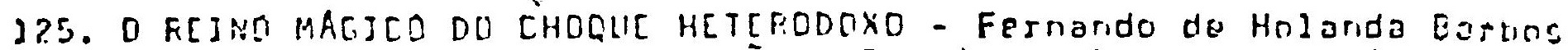
Antoriac solozir Pessua brancío c Clovis de Faro - jyos lesgutado

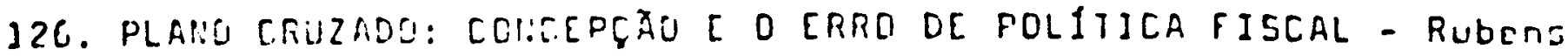
Pento Cystro - 2988

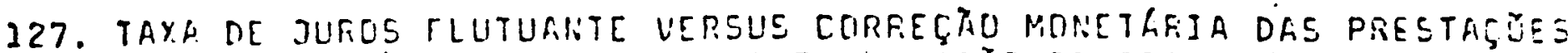

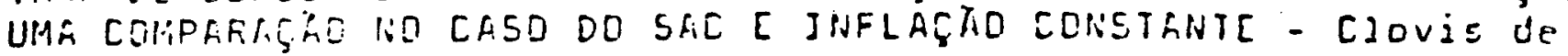
Faro - 1955

128. CAPITULO II - MONETAFY CURRECTION AND REAL INTEREST ACCOUHTINO - Rutiene Fentia Cysne - 1988

129. CAP17ULO JII - IREOGE ANDDEMAND POLICIES IN BRAZIL - RUGENE Pente Cyene - 1908

130. CAPITULO IV - BFAZILIAH ECCNOMY IN THE EIGHTIES AND THE DEET CRISIS - Rubers FEnha CYSnE - $198 B$

231. THE EFÁZILIAN FGFICULTURAL POLICY EXPERIEHCE: RATIONALE AND FUTURL DIfEetion:S - Antonio Selazar Pessoa Branoão - 1988

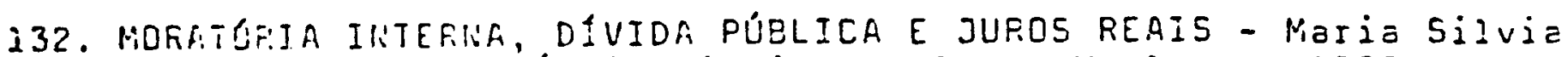
Bastos lierques e Sézgio Ribejro de Costa lierlang - iges

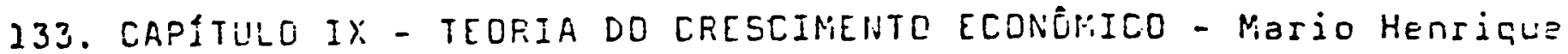
Simonsen - $198 \mathrm{C}$

134. CONGELRMENTO COH AEOWO SALARIAL GERANDO EXCESSO DE DEMANDA -

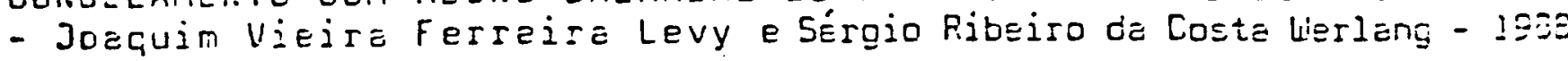

335. AS ORIGENS E CONSEQUENCIAS. DA IRFLAÇX̃O NA AMERICA LATIMA Ferriando de Holanda Barbosa - 1988

136. A CONTA-COFRENTE DO GOVERNO - 1970-1988 - Mario Heririque Simonsen - 1989

137. A REVIEL OH: THE THEORY OF COMHON KNOULEDGE

- Sérgio Ribeiro da Costa Weriang - 1989

138. RPACRCECONORIA

- Fernando de Holenda Bertosa - 1989 (esgotadu)

139. TEORID DD EALALCZO DE FAGAMENTOS: UMA ABDRDAGEM SIMPLIFICADA -

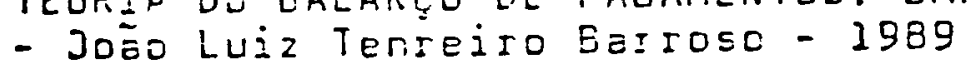

140. CORTAEILIDADE COM JUROS REALS - RUBEHS PERTA CYSNE - 1989

141. "CFEDIT RATIONING ANO THE PERMANENT IHCOME hYPOTHESIS" - Vicente Madriçal, Tomty Tan, Daniel Vicent, Sérgio Ribeiro da costa kerlang - 1989

142. "A AMAZONIA BRASILEIRA" - Ney Coe de Oliveira - 1999

143. DESFGIO DR:S LFTS E A PROBAPILIDADE INPLICITA DE MORATCIAA Meria Silvia Eastos Marques e Sérgio Riteiro da Costa Verlang- IE

144. THE LOC DEBT PROBLEM: A GAME-THEORETICAL ANALYSIS Mario Henrique Simonsen e Sërgio Ribeiro da Costa Werlang- 1989

145. ANALISE CONVEXA NO $R^{n}$ - Mario Henrique Simonsen - 1989

146. A CONTROVERSIA MONETARISTA NO HEMISFERIO NORTE

Fernando de Holanda Barbosa - 1989

147. FISCAL REFORM ANO STABILIZATION: THE GRAZILIAN EXPERIENCE - Fernando de HOlimirio Barbosa, António Sslazar Pessoa Brondão e Clovis de Faro - 1989 
148. RETCR:iOS EH EDLCRÇ ITO NO BRASIL: 1976-1986

Carlos Ivan Simonson Leal e Sérgio Ribeiro da Costa Werlang - 1983

149. PREFERERCES, COMYO KNONLEDGE, AND SPECULATIVE TRADE - James DON, Vicente Hajoigal, Sérgio Ribeiro da Costa Werlang - 1990

150. EDUCACÑO E, DISTRIBUICAO DE RENDA

Carlos Ivan Simonson Leal e Sérgio Ribeiro da Costa - 1990

151. OBSERVAÇÕES À MARGEN DO TRABALHO "A AMAZONIA BRASILEIRA" - NeY Coe de Oliveira - 1990

152. PLANO COLLOR: LM GOLPE DE MESTRE CONTRA A INFLAÇ To?

- Fernandio de Holanda Barbosa - 1990

153. O EFEITO DA TAXA DE JUROS E DA INCERTEZA SOBRE A CURVA DE PHILIFS DA ECONOMJA BRASILEIRA - Ricardo de Oliveira Cavalcanti - 1990

154. PLANO COLLOR: CONTRA FACTUALIDADE E SUGESTOES SOBRE À CONDUÇÃO DA POLITICA MONETRRJA-FISCAL - Rubens Penha Cysne - 1990

155. DEPÓSITOS DO TESOURO: NO BANCO CENTRAL OU NOS BANCOS CONERCIAIS? Rubens Penha Cysne - 1990

156. SISTEMA FINANCEIRO DE HABITAÇÃO: A QUESTÃO DO DESEQUILIBRIO DO FCVS - Clovis de Faro - $1990^{\circ}$

157. COMPLEMENTO DO FASCICULO No 151 DOS "ENSAIOS ECONOMICOS" (A MNAZONIA BRASILEIRA) - NeY Coe cie Oliveira - 1990

158. POLITICA MCNETARIA OTIMA NO COMBATE À INELAÇÃO

- Fernando de holanda Barbosa - 1990

159. TEORIA DOS JOGOS - CONCEITOS BASICOS - Mario Henrique Simonson $-1990$

160. O MERCADO ARERTO RRASILEIRO: ANALISE DOS PROCEDIMEUTOS OPERACIO. NAIS - Fernando de Holanda sarbosa - 1990

161. A RELAÇRO ARBITRAGEM ENTRE A ORTN CAMBIAL E A CRTN NCNETSRIA - Luiz Guilherme schymura de oliveira - 1990

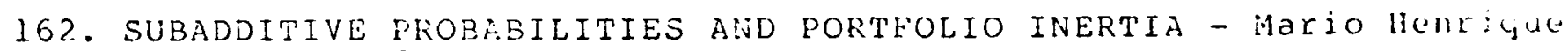
Simonser e Sérgio Ribeiro da Costa Werlang - 1990

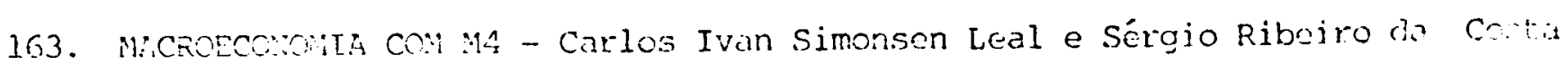
Werlang - 1990

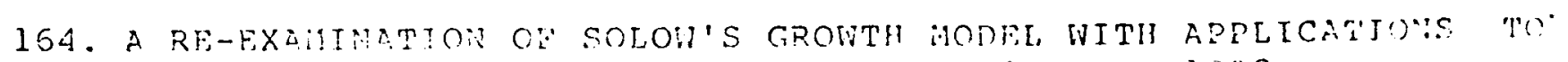

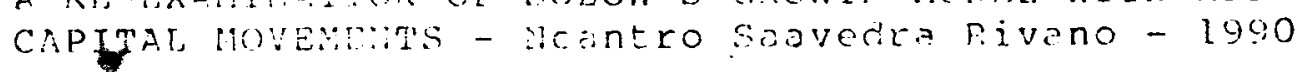

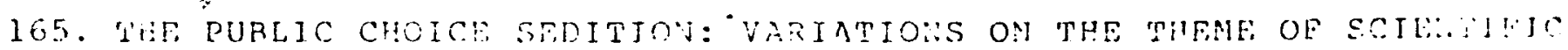
WAPFARE - AnEonio baria a silvare - logo

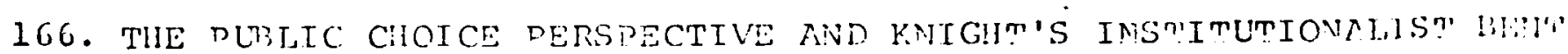

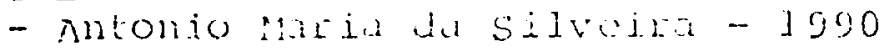

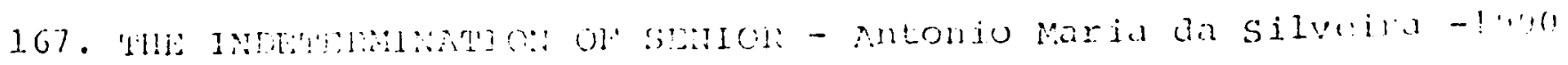


168. JAPANESE DIRECT INVESTMENT IN BRAZIL - Neantro Saavedra Riva no -1990

169. A CARTEIRA DE AÇÕES DA CORRETORA: UMA ANÁLISE ECONOMICA-Luiz Guilherme Schymura de Oliveira - 1991

170. PLANO COLLOR: OS PRIMEIROS NOVE MESES - Clovis de Faro -1991

171. PERCALÇOS DA INDEXAÇÃo-EX-ANTE - Clovis de Faro - 1991

172. NOVE PONTOS SOBRE O PLANO COLLOR II - Rubens Penha CYsne-19991

173. A DINAMICA DA HIPERINFLAÇÃo - Fernando de H. Barbosa, Waldyr Muniz Oliva e Elvia Mureb Sallum - 1991

174. LOCAL CONCAVIFIABILITY OF PREFERENCES AND DETERMINACY OF EqUILIbRIUM - Mario Rui Pascoa e Sérgio Ribeiro da Costa Wer lang - Maio de 1991

175. A CONTABILIDADE DOS AGREgAdOS MONETÁRIOS NO BRASIL - Carlos Ivan Simonsen Leal e Sérgio Ribeiro da Costa Werlang - maio de 1991.

176. homothetic PREFEREnCES - James Dow e Sérgio Ribeiro da Costa Werlang - 1991

177. RARREIRAS $\bar{A}$ ENTRADA NAS INDUSTRIAS: 0 PAPEL DA FIRMA PIONEIRA Luiz Guilherme Schymura de Oliveira - 1991.

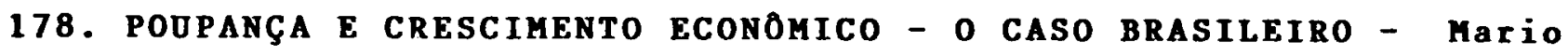
Hentique Simonsen - agosto de 1991.

179. EXCESS VOLATILITY OF STOCK PRICES AND KNIGHTIAN UNCERTAINTY ${ }^{\circ}$ James Dow e Sérgio Ribeiro da costa Werlang - 1991. 
$A C: 36727$

BJBLIOTECA

MARIO HENRIQUE SIMONSEN UNDACAO GETULIO VARGAS

$439 / 91 \ln 30 / 10 / 91$ 10: $5+172$ 